\title{
DAMPAK IMPOR GULA TERHADAP PRODUKSI TEBU DAN HARGA GULA DOMESTIK DI INDONESIA
}

\author{
Safrida $^{1 *}$, Sofyan ${ }^{2}$, Adawiya Taufani ${ }^{3}$ \\ ${ }^{1}$ Prodi Agribisnis Universitas Syiah Kuala, Banda Aceh, safrida@unsyiah.ac.id \\ ${ }^{2}$ Prodi Agribisnis Universitas Syiah Kuala, Banda Aceh \\ ${ }^{3}$ Prodi AgUniversitas Syiah Kuala, Banda Aceh
}

\begin{abstract}
A B S T R A K
Gula merupakan salah satu produksi dari subsektor perkebunan yang berasal dari tanaman tebu. Selama tahun 2005-2016, produksi tebu Indonesia cenderung menurun, sementara konsumsi gula semakin meningkat. Untuk memenuhi konsumsi tersebut, Indonesia melakukan impor gula dengan harga yang lebih rendah dari harga gula dalam negeri. Namun dampaknya adalah terjadinya penurunan produksi tebu di Indonesia. Kondisi ini tidak sesuai dengan tujuan dari kegiatan impor. Secara teori, impor hanya untuk memenuhi kebutuhan dalam negeri dan tidak mempengaruhi produksi. Ketika impor meningkat, produksi gula dalam negeri seharusnya juga meningkat untuk mengurangi ketergantungan terhadap impor. Penelitian ini bertujuan untuk mengetahui dampak impor gula terhadap produksi tebu dan harga gula domestik di Indonesia. Data yang digunakan pada penelitian ini adalah data sekunder dalam bentuk data time series tahun 1997-2016. Penelitian ini menggunakan model regresi persamaan simultan dengan 7 persamaan yang terdiri dari 6 persamaan struktural dan 1 persamaan identitas. Hasil penelitian menunjukkan bahwa: (1) trend dan proyeksi impor gula, produksi tebu dan harga gula pada lima tahun yang akan datang terus meningkat, (2) impor gula berdampak pada turunnya produksi tebu di Indonesia, (3) impor gula juga berdampak pada peningkatan harga gula domestik.
\end{abstract}

Kata Kunci: gula, tebu, produksi, impor, harga

\begin{abstract}
Sugar is one of the production from the plantation sub-sector derived from sugar cane. During 20052016, Indonesian sugarcane production tended to decrease, while sugar consumption increased. To fulfill this consumption, Indonesia imports sugar at prices lower than domestic sugar prices. However, the impact of sugar imports is the decline in sugarcane production in Indonesia. This condition is not accordance with the objectives of the import activity. In theory, imports are only to meet domestic needs and do not affect production. When imports increase, domestic sugar production should also increase to reduce dependence on imports. This study aims to determine the impact of sugar imports on sugarcane production and domestic sugar prices in Indonesia. The data used in this study are secondary data in the form of time series data for 1997-2016. This study uses a simultaneous equation regression model with 7 equations consisting of 6 structural equations and 1 identity equation. The results showed that: (1) the trend and projection of sugar imports, sugarcane production and sugar prices in the coming five years continues to increase, (2) sugar imports have an impact on the decline in sugarcane production in Indonesia, (3) sugar imports also have an impact on increasing domestic sugar prices.
\end{abstract}

Keywords: sugar, sugarcane, production, import, price 


\section{PENDAHULUAN}

Selama 10 tahun terakhir konsumsi gula di Indonesia meningkat $53.33 \%$ sementara produksi menurun sebesar $11,1 \%$. Konsumsi gula nasional pada tahun 2016 mencapai 5,75 juta ton jauh lebih tinggi dibandingkan konsumsi nasional pada tahun 2008 yang hanya 3,5 juta ton (Gambar 1). Peningkatan konsumsi tersebut tidak diimbangi dengan peningkatan produksi tebu sebagai bahan baku pembuat gula. Akibatnya untuk memenuhi kebutuhan gula dalam negeri baik untuk konsumsi rumah tangga maupun industri, Indonesia harus mengimpor gula. Volume dan nilai impor gula Indonesia terus mengalami peningkatan dari tahun ke tahun. Jika kondisi ini terus terjadi, maka ketergantungan Indonesia terhadap gula impor akan terus meningkat. Disisi lain, pemerintah melalui Program Revitalisasi Industri Gula BUMN dan BUMS Tahun 2010-2014, menargetkan tahun 2014
Indonesia akan mencapai swasembada gula. Revitalisasi tersebut meliputi: (1) Revitalisasi sektor on-farm yaitu perluasan areal dan peningkatan produktivitas gula dan (2) revitalisasi sektor off-farm: rehabilitasi, peningkatan kapasitas giling amalgamasi, peningkatan efisiensi pabrik, dan peningkatan kualitas gula. Namun swasembada gula masih belum tercapai, Tahun 2015-2016, Indonesia masih mengimpor gula untuk memenuhi konsumsi gula dalam negeri. Bahkan jumlah impor gula pada tahun tersebut lebih tinggi dibandingkan tahun sebelumnya. Ketergantungan yang terus menerus terhadap impor, akan merugikan ekonomi Indonesia (Gambar 1). Secara makro, tingginya impor dalam waktu yang lama diduga akan mengganggu produksi dalam negeri dan mengancam ketahanan pangan nasional yang akan berdampak pada defisit neraca perdagangan.

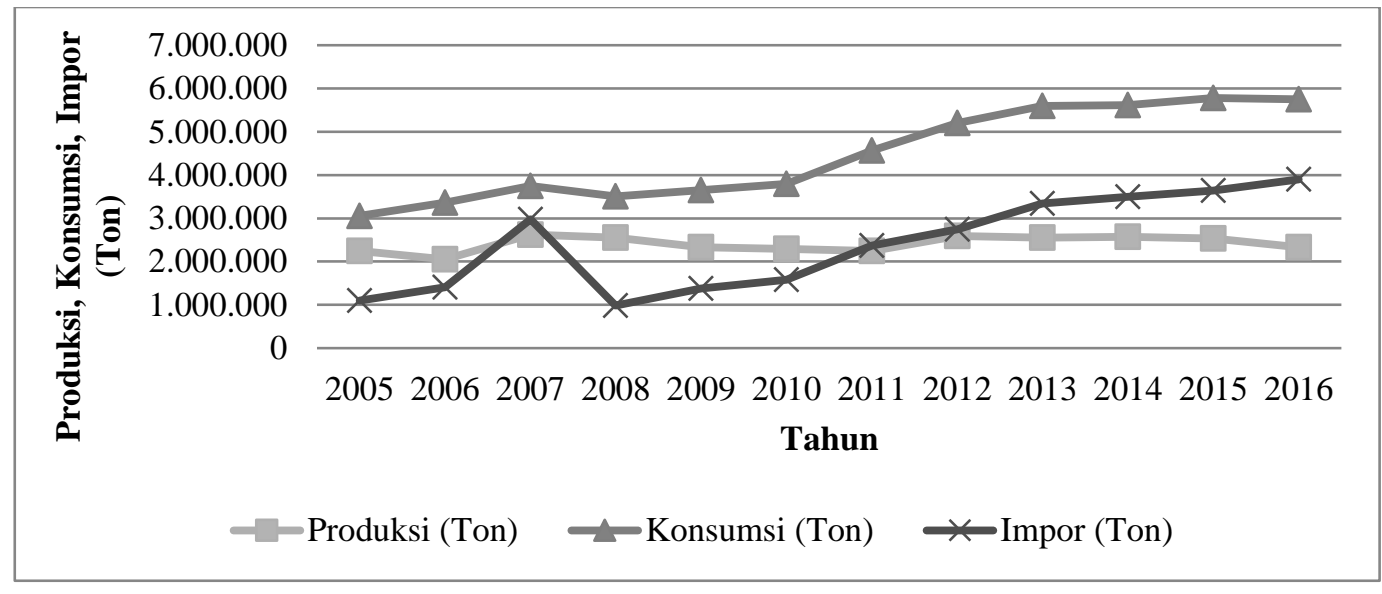

Sumber : Badan Pusat Statistik

Gambar 1. Pekembangan Produksi, Konsumsi, dan Impor Gula Nasional Tahun 2005-2016

Ketika volume impor gula terus meningkat, produksi tebu mengalami fluktuasi dan cenderung menurun. Kondisi ini disebabkan oleh masuknya gula impor dengan harga murah yang mengakibatkan gula nasional kehilangan sebagian pasarnya sehingga terjadi ketidakstabilan harga gula lokal. Harga yang tidak stabil ini dikhawatirkan akan menurunkan gairah dan partisipasi petani dalam budidaya tebu, yang selanjutnya berdampak pada produksi yang dihasilkan. Berdasarkan masalah tersebut, maka perlu dianalisis bagaimana pengaruh impor gula terhadap produksi 
tebu dan harga gula di Indonesia. Dengan demikian diharapkan dapat memberikan kontribusi bagi pengambil kebijakan sehubungan dengan pergulaan nasional.

Tujuan dari penelitian ini adalah mengetahui trend dan proyeksi volume impor gula, produksi tebu dan harga gula domestik selama 5 tahun yang akan dating, serta menganalisis dampak impor gula terhadap produksi tebu dan harga gula domestik di Indonesia.

\section{METODE PENELITIAN}

\section{Jenis dan Sumber Data}

Penelitian ini merupakan penelitian kuantitatif, dengan menggunakan data sekunder dalam bentuk time series tahunan dengan rentang waktu penelitian tahun 1997-2016. Data tersebut diperoleh dari beberapa instansi terkait, seperti Badan Pusat Statistik (BPS), Kementerian Perdagangan Republik Indonesia (Kemendag RI), Dinas Perdagangan dan Perindustrian, Direktorat Jendral Perkebunan (Ditjenbun), Kementerian Pertanian Republik Indonesia (Kementan RI), Kementerian Keuangan Republik Indonesia (Kemenkeu RI), Ditjen Bea dan Cukai, Bank Indonesia, website FAO, Bank Dunia, Pusat Data dan Informasi Pertanian serta berbagai literatur yang menunjang penyusunan penelitian ini.

\section{Model Analisis}

Model analisis dalam penelitian ini menggunakan:

\section{Analisis Trend (untuk analisis trend} impor gula)

Analisis trend dalam analisis ini menggunakan analisis trend linear, dengan persamaan:

$Y_{i}=a+b X ; a=\frac{\sum Y}{n}, b=$ $\frac{\sum \mathrm{XY}}{\mathrm{X}^{2}}$

Dimana :

$$
\begin{aligned}
\mathrm{Y}_{\mathrm{i}}= & \text { Volume impor dan } \\
& \text { harga gula } 5 \text { tahun yang } \\
& \text { akan datang } \\
\mathrm{X}= & \text { Periode waktu } \\
\mathrm{a}= & \text { Konstanta model } \\
\mathrm{b}= & \text { Besarnya perubahan } \\
& \text { variabel yang terjadi } \\
& \text { pada setiap perubahan } \\
& \text { satu unit variabel } \mathrm{X} . \\
\mathrm{Y}= & \text { Volume impor dan } \\
& \text { harga gula } \\
\mathrm{n}= & \text { Banyaknya data }
\end{aligned}
$$

2. Analisis Regresi Persamaan Simultan (Untuk analisis dampak impor gula terhadap produksi tebu dan harga gula di Indonesia)

Dalam analisis ini menggunakan tujuh persamaan yang terdiri dari 6 persamaan struktural dan 1 persamaan identitas. Sebelum model persamaan tersebut dianalisis, maka perlu dilakukan identifikasi model. Hasil identifikasi model menggunakan order condition, yang menunjukkan bahwa setiap persamaan dalam kondisi over identified.

Model persamaan simultan dalam analisis ini adalah:

a. Persamaan Indentitas :

Prt $=\mathrm{LP}_{\mathrm{t}} \cdot \operatorname{Prdv}_{\mathrm{t}}$

Prt $=$ Produksi tebu (ton)

$\mathrm{LP}_{\mathrm{t}} \quad=$ Luas areal tebu (Ha)

$\operatorname{Prdv}_{\mathrm{t}}=$ Produktivitas tebu $(\mathrm{Ton} / \mathrm{Ha})$

b. Persamaan Stuktural :

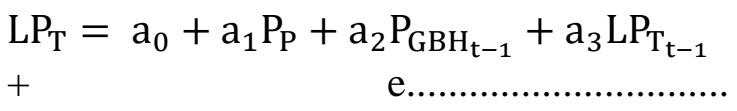

(4)

Nilai yang diharapkan $\mathrm{a}_{1}, \mathrm{a}_{3}>0 ; \mathrm{a}_{2}<0$

$\mathrm{PRDV}_{\mathrm{T}}=\mathrm{b}_{0}+\mathrm{b}_{1} \mathrm{P}_{\mathrm{P}}+\mathrm{b}_{2} \mathrm{P}_{\mathrm{PUK}_{\mathrm{t}-1}}+$

$b_{3} R_{D M N}+b_{4} P R_{D V} V_{t-1}+$ e. 
Nilai yang diharapkan $b_{1}, b_{3}, b_{4} ; 0$, dan $b_{2}$ $<0$

$\mathrm{P}_{\mathrm{P}}=\mathrm{c}_{0}+\mathrm{c}_{1} \mathrm{PR}_{\mathrm{T}}+\mathrm{c}_{2} \mathrm{P}_{\mathrm{IG}}+\mathrm{c}_{3} \mathrm{M}_{\mathrm{G}}+$ $\mathrm{c}_{4} \mathrm{D}_{\mathrm{DN}}+\mathrm{c}_{5} \mathrm{P}_{\mathrm{P}_{\mathrm{t}-1}}+\mathrm{e}$.

Nilai yang diharapkan $\mathrm{c}_{2}, \mathrm{c}_{4}, \mathrm{c}_{5} ; 0, \mathrm{c}_{1}, \mathrm{c}_{3}<0$ $\mathrm{P}_{\mathrm{IG}}=\mathrm{d}_{0}+\mathrm{d}_{1} \mathrm{P}_{\mathrm{W}}+\mathrm{d}_{2} \mathrm{M}_{\mathrm{G}}+\mathrm{d}_{3} \mathrm{NT}+\mathrm{d}_{4} \mathrm{TI}_{\mathrm{t}-1}$ $+$

Nilai yang diharapkan $\mathrm{d}_{1}, \mathrm{~d}_{3}, \mathrm{~d}_{4} ; 0, \mathrm{~d}_{2}<0$ $\mathrm{M}_{\mathrm{G}}=\mathrm{e}_{0}+\mathrm{e}_{1} \mathrm{P}_{\mathrm{DN}}+\mathrm{e}_{2} \mathrm{P}_{\mathrm{W}}+\mathrm{e}_{3} \mathrm{NT}+$ $\mathrm{e}_{4} \mathrm{Y}+\mathrm{e}_{5} \mathrm{TI}_{\mathrm{t}-1}+\mathrm{e}$

(8)

Nilai yang diharapkan $\mathrm{e}_{1}, \mathrm{e}_{4}>0 ; \mathrm{e}_{2}, \mathrm{e}_{3}$, $\mathrm{e}_{5}<0$

$\mathrm{P}_{\mathrm{DN}}=\mathrm{f}_{0}+\mathrm{f}_{1} \mathrm{P}_{\mathrm{P}}+\mathrm{f}_{2} \mathrm{P}_{\mathrm{W}}+\mathrm{f}_{3} \mathrm{M}_{\mathrm{G}}+$ $\mathrm{f}_{4} \mathrm{NT}+\mathrm{f}_{5} \mathrm{P}_{\mathrm{DN}_{\mathrm{t}-1}}+$

Nilai yang diharapkan $\mathrm{f}_{1}, \mathrm{f}_{2}, \mathrm{f}_{4} \mathrm{f}_{5}>0 ; \mathrm{f}_{3}<$ 0

Dimana :

Prt = Produksi tebu (ton)

$\mathrm{LP}_{\mathrm{t}} \quad=$ Luas areal tebu $(\mathrm{Ha})$

$\operatorname{Prdv}_{\mathrm{t}}=$ Produktivitas tebu $(\mathrm{Ton} / \mathrm{Ha})$

$\mathrm{P}_{\mathrm{P}} \quad=$ Harga gula tingkat petani (Rp/ton)

$\mathrm{P}_{\mathrm{GBH}_{\mathrm{t}-1}}=$ Lag Harga gabah (Rp/ton)

$\mathrm{LP}_{\mathrm{T}_{\mathrm{t}-1}}=\mathrm{Lag}$ Luas areal tebu $(\mathrm{Ha})$

$\mathrm{P}_{\mathrm{PUK}_{\mathrm{t}-1}}=$ Lag Harga pupuk $(\mathrm{Rp} / \mathrm{Kg})$

$\mathrm{R}_{\mathrm{DMN}}=$ Rendemen tebu $(\%)$

$\mathrm{PRDV}_{\mathrm{T}_{\mathrm{t}-1}}=\mathrm{Lag}$ Produktivitas (ton/Ha)

$\mathrm{PR}_{\mathrm{t}} \quad=$ Produksi tebu (ton)

$\mathrm{P}_{\mathrm{IG}} \quad=$ Harga impor gula $(\mathrm{Rp} / \mathrm{ton})$

$\mathrm{M}_{\mathrm{G}} \quad=$ Volume impor gula (ton)

$\mathrm{D}_{\mathrm{DN}}=$ Permintaan gula dalam negeri (ton)

$\mathrm{P}_{\mathrm{P}_{\mathrm{t}-1}}=$ Lag harga gula tingkat petani (Rp/ton)

$\mathrm{P}_{\mathrm{W}} \quad$ = Harga gula dunia (USD/ton)

$\mathrm{TI}_{\mathrm{t}-1}=$ Lag tarif impor gula (Rp/ton)

$\mathrm{P}_{\mathrm{DN}} \quad=$ Harga gula domestik $(\mathrm{Rp} / \mathrm{kg})$

NT = Nilai tukar rupiah

$\mathrm{P}_{\mathrm{DN}_{\mathrm{t}-1}}=$ Lag Harga gula domestik (Rp/ton)

\section{Uji Hipotesis}

a. Uji F
Untuk melihat apakah variabel eksogen secara serempak berpengaruh nyata terhadap variabel endogennya. Adapun rumusnya yaitu :

$\mathrm{F}_{\text {hitung }}=\frac{\mathrm{R}^{2} / \mathrm{k}}{\left(1-\mathrm{R}^{2}\right)-(\mathrm{n}-\mathrm{k}-1)}$

Dengan kriteria terima $\mathrm{H}_{\mathrm{a}}$ dan tolak $\mathrm{H}_{0}$, jika $\mathrm{P}_{\text {value }}<0,05$ atau $\mathrm{F}_{\text {hit }}>\mathrm{F}_{\text {tabel }}$, dan sebaliknya.

b. Uji $R^{2}$

Untuk melihat sejauh mana variabel eksogen mampu menjelaskan variabel endogennya. Rumusnya sebagai berikut :

c. Uji t

$$
\mathrm{R}^{2}=\frac{\mathrm{JK}(\mathrm{reg})}{\sum \mathrm{yi}^{2}}
$$

Untuk mengetahui pengaruh nyata masing-masing variabel eksogen terhadap variabel endogennya.

$$
t_{\text {hitung }}=\frac{b_{i}}{s b_{i}}
$$

Dengan kriteria terima $\mathrm{H}_{\mathrm{a}}$ dan tolak $\mathrm{H}_{0}$, jika $\mathrm{P}_{\text {value }}>0,05$ atau $\mathrm{t}_{\text {hit }}>\mathrm{t}_{\text {tabel }}$, dan sebaliknya.

\section{HASIL DAN PEMBAHASAN}

\section{Hasil Analisis Trend dan Peramalan Trend Impor Gula}

Indonesia merupakan salah satu negara yang masih menggantungkan pemenuhan konsumsi gulanya dari gula impor. Impor gula di Indonesia dalam kurun waktu 1997 sampai 2016 mengalami fluktuasi dengan kecenderungan yang meningkat. Kondisi ini disebabkan oleh produksi tebu di Indonesia masih tergolong rendah, sementara permintaan dan harga gula dalam negeri terus mengalami peningkatan. Adapun trend linear volume impor gula di Indonesia dapat dilihat pada gambar berikut : 


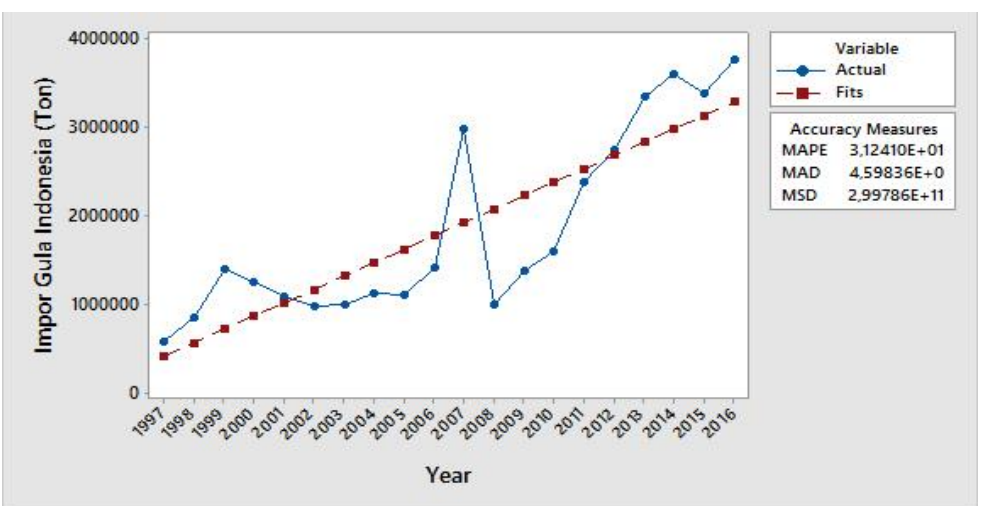

Gambar 2. Trend Analysis Plot For Import Gula Indonesia 1997-2016

Gambar 2 memperlihatkan kondisi trend impor gula yang meningkat. Peningkatan impor mulai terjadi pada tahun 1998, karena pada saat itu Indonesia mengalami krisis ekonomi, selain itu ditahun tersebut dikeluarkannya letter of intent yang ditandatangani oleh pemerintah dan IMF (International Monetary Fund) yang menyepakati untuk menghapus bea masuk gula menjadi 0\% sehingga pasar gula Indonesia dipenuhi oleh gula impor dengan harga yang lebih murah (Adriyanto,2012). Tahun 1999 disepakati bea masuk gula sebesar $25 \%$ yang

$$
\mathrm{Yt}=253198+151306 \mathrm{t}
$$

Tabel 2. Forecast Impor Gula Indonesia 5 Tahun Yang Akan Datang

\begin{tabular}{cc}
\hline Tahun & Hasil Forecast (Ton) \\
\hline 2017 & 3.430 .617 \\
2018 & 3.581 .922 \\
2019 & 3.733228. \\
2020 & 3.884 .534 \\
2021 & 4.035 .839 \\
\hline
\end{tabular}

Berdasarkan hasil proyeksi ini, memberi gambaran kondisi impor gula yang semakin meningkat, sehingga diperlukan kebijakan dari pemerintah dan pihak-pihak terkait untuk mendorong produksi tebu dalam negeri untuk mengurangi volume impor yang terus meningkat hingga saat ini.

\section{Trend Produksi Tebu}

bertujuan untuk megurangi jumlah impor. Perubahan tarif impor terus dilakukan untuk mengurangi impor, hingga pada tahun 2016 tarif menjadi Rp.790/kg untuk gula pasir. Namun pemerintah belum juga berhasil menurunkan volume impor gula, karena tingginya permintaan gula dibandingkan dengan produksinya. Kondisi ini dapat dilihat dari terus meningkatnya volume impor hingga tahun 2016. Adapun hasil proyeksi impor 5 tahun yang akan datang dari persamaan yang dihasilkan sebagai berikut : 


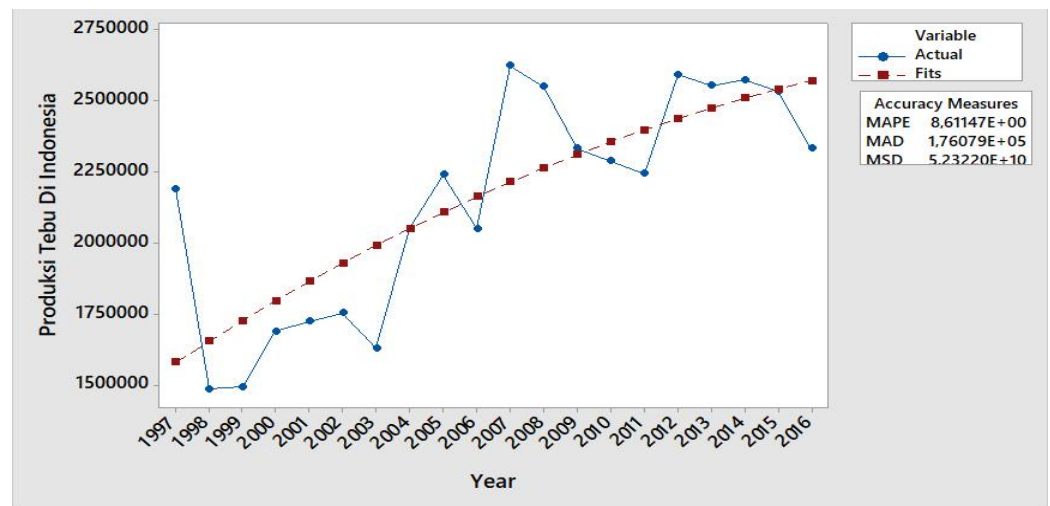

Gambar 3. Quadratic Trend Analysis Plot For Produksi Tebu Di Indonesia 1997-2016

Dalam beberapa tahun terakhir, produksi tebu di Indonesia mengalami fluktuasi yang cenderung menurun. Penurunan produksi tebu mulai terjadi pada tahun 1998. Tahun 2004 pemerintah menetapkan HPP (harga pokok pembelian) yang bertujuan untuk melindungi petani tebu, sehingga pada tahun tersebut produksi tebu diharapkan dapat ditingkatkan. HPP adalah harga patokan terendah yang ditetapkan pemerintah untuk membeli harga gula ditingkat petani. Namun HPP ini tidak serta merta berjalan lancar, karena pemerintah juga berusaha melindungi konsumen dengan harga yang berlaku ditingkat konsumen (Nusantara Sugar Club, 2014). Beberapa tahun selama periode panelitian harga lelang (harga gula ditingkat petani) berada dibawah HPP bahkan dibawah biaya pokok produksi tebu (BPP), yang mungkin juga akan berdampak pada produksi tebu yang dihasilkan Adapun hasil proyeksi produksi tebu 5 tahun yang akan datang berdasarkan persamaan trend:

$$
\mathrm{Yt}=1503655+78448 \mathrm{t}-1252 \mathrm{t}^{2}
$$

Tabel 3. Forecast Produksi Tebu Indonesia 5 Tahun Yang Akan Datang

\begin{tabular}{cc}
\hline Tahun & Hasil Forecast (Ton) \\
\hline 2017 & 2.598 .774 \\
2018 & 2.623 .371 \\
2019 & 2.645 .463 \\
2020 & 2.665 .050 \\
2021 & 2.6821 .33 \\
\hline
\end{tabular}

Berdasarkan hasil proyeksi 5 tahun yang akan datang, dapat dilihat bahwa produksi tebu di Indonesia terus mengalami peningkatan meskipun dengan tingkat pertumbuhan yang rendah. Namun hal ini memberikan harapan bagi produksi dalam negeri untuk dapat mewujudkan swasembada gula, meskipunpun tidak dalam waktu dekat. Oleh karena itu diperlukan berbagai upaya untuk meningkatkan produksi gula dalam negeri, sehingga dapat mengurangi ketergantungan Indonesia terhadap impor.

\section{Trend Harga Gula Domestik}

Harga gula domestik merupakan harga gula yang berlaku ditingkat konsumen di Indonesia. Tinggi rendahnya harga dapat berdampak pada stabilitas perekonomian dalam negara. Harga gula yang tinggi dapat menyumbangkan inflasi bagi suatu negara. Gula merupakan salah satu bahan pokok yang menyumbangkan inflasi di Indonesia (Bank Indonesia, 2007). Adapun trend harga gula selama periode penelitian 1997 sampai 2016 sebagai berikut : 


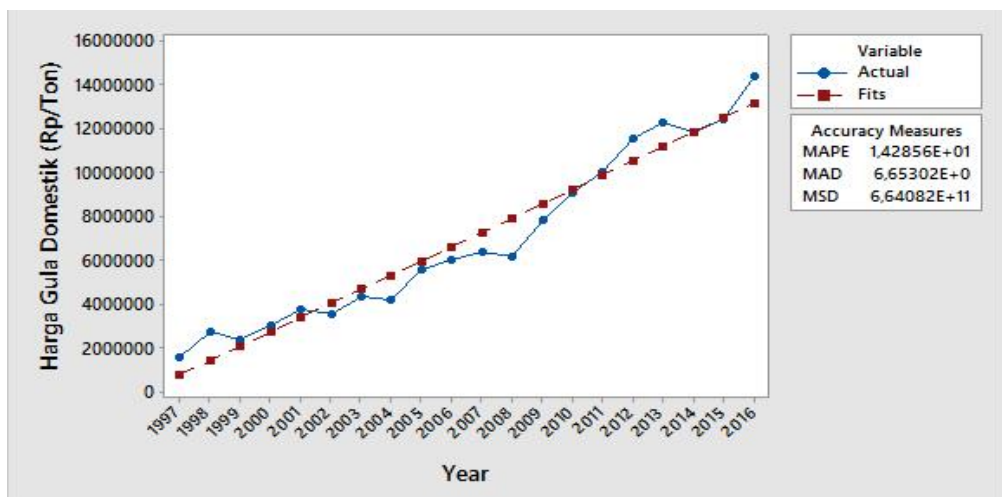

Gambar 4. Linear Trend Analysis Plot For Harga Gula Domestik 1997-2016

Gambar 4. memperlihatkan trend harga gula di Indonesia yang terus mengalami peningkatan setiap tahunnya. Tahun 1998 harga gula domestik mengalami peningkatan seratus persen dari harga gula tahun sebelumnya. Namun tahun 1999 harga gula kembali menurun, yang disebabkan oleh turunnya harga gula dunia, dan menguatnya nilai tukar rupiah (Wahyuni et al, 2009). Tahun-tahun selanjutnya harga gula di Indonesia terus mengalami peningkatan. Kondisi ini disebabkan oleh produksi gula nasional yang tidak dapat memenuhi kebutuhan dalam negeri sehingga meningkatkan harga gula dalam negeri, meskipun Indonesia telah melakukan impor gula. Oleh karena itu salah satu cara untuk menstabilkan harga yaitu dengan meningkatkan produksi agar dapat memenuhi kebutuhan dalam negeri. Adapun proyeksi harga dalam 5 tahun yang akan datang berdasarkan persamaan berikut :

$$
Y t=77326+653067 t
$$

Tabel.4 Forecast harga gula domestik (Rp/ton) 5 tahun yang akan datang

\begin{tabular}{cc}
\hline Tahun & Hasil Forecast $(\mathrm{Rp} /$ Ton $)$ \\
\hline 2017 & 13.791 .724 \\
2018 & 14.444 .790 \\
2019 & 15.097 .857 \\
2020 & 15.750 .923 \\
2021 & 16.403 .990 \\
\hline
\end{tabular}

Tabel 4 memperlihatkan tahun 2017 harga gula dalam negeri mengalami penurunan dibandingkan tahun 2016, hal ini sesuai dengan kenyataan yang terjadi dimana harga gula tahun 2107 menurun menjadi Rp.12.500/kg. Menurut data APTRI (2018), turunnya harga gula tahun 2017 disebabkan oleh meningkatnya stok gula nasional yang diakibatkan oleh tingginya impor gula sejak pada tahun 2016. Namun tahun berikutnya harga gula cenderung meningkat sampai dengan tahun 2021. Oleh karena itu diperlukan berbagai upaya utuk menstabilkan harga gula dalam negeri tanpa harus bergantung terhadap impor.

\section{Hasil Estimasi Persamaan Simultan Faktor Yang Mempengaruhi Produksi Tebu}

Persamaan produksi tebu pada penelitian ini merupakan persamaan identitas dari hasil kali luas areal tebu dengan produktivitasnya.

$$
\operatorname{Prt}=\mathrm{LP}_{\mathrm{t}} \cdot \operatorname{Prdv}_{\mathrm{t}}
$$

Setiap perubahan faktor yang mempengaruhi luas areal dan produktivitas 
maka akan mempengaruhi produksi tebu. Apabila luas areal dan produktivitas meningkat, maka produksi tebu juga akan meningkat.

\section{Faktor Yang Mempengaruhi Luas Areal Tebu}

Luas areal tebu $\left(\mathrm{LP}_{\mathrm{t}}\right)$ pada penelitian ini dipengaruhi oleh harga gula $\mathrm{LP}_{\mathrm{t}}$ sebesar $91.52 \%$, selebihnya dijelaskan oleh faktor lainnya diluar model.

Tabel. 5 Hasil Estimasi Faktor Yang Mempengaruhi Luas Areal Tebu

\begin{tabular}{ccccccc}
\hline & Coefficient & thitung & t $_{\text {tabel }}$ & $\mathbf{P}_{\text {value }}$ & Esr & Elr \\
\hline Constant & 80275,39 & 1.51 & & 0.130 & & \\
$\mathbf{P}_{\mathbf{P}}$ & 0,0104684 & 2,44 & 2,11 & 0.017 & 0.15 & 0.55 \\
Pgbh $_{\mathbf{t}-\mathbf{1}}$ & -0.0114192 & $-1,05$ & & 0.295 & -0.07 & -0.26 \\
$\mathbf{L P}_{\mathbf{t}-\mathbf{1}}$ & 0.7300007 & 4,52 & & 0.000 & 0.72 & 2,67 \\
\hline $\mathbf{F}$ & & 70,69 & & \\
$\mathbf{R}^{2}$ & & 91,52 & & \\
\hline
\end{tabular}

Dari tabel diatas, maka bentuk persamaannya sebagai berikut :

$$
L P_{t}=80275,39+0,0104684 P_{p}-0,0114192 P_{g b h}+0.7300007 L P_{t-1}
$$

Tabel 5 memperlihatkan bahwa faktor yang berpengaruh nyata terhadap luas areal tebu adalah harga gula ditingkat petani dan lag luas areal tebu pada tingkat kepercayaan $95 \%$. Kedua variabel ini berpengaruh positif terhadap luas areal tebu, artinya jika harga gula ditingkat petani naik sebesar Rp.100 maka akan meningkatkan luas areal tebu sebesar 1,04684 Ha. Nilai lag luas areal tebu yang positif menunjukkan adanya kecenderungan peningkatan luas lahan tebu dari tahun ke tahun. Menurut Arifin (2008) peningkatan produksi dan produktivitas tidak mungkin tercapai apabila harga beli ditingkat petani rendah. Harga jual akan mempengaruhi pendapatan yang diperoleh, yang berdampak pada meningkatnya gairah petani untuk menanam suatu komoditi pertanian. Harga gabah tidak berpengaruh nyata terhadap luas areal tebu tetapi memberikan pengaruh negatif. Penurunan luas areal tebu juga semakin tersisih oleh komoditas lain seperti padi, hortikultura, dan palawija yang secara ekonomi lebih menguntungkan (Arifin, 2008).

\section{Faktor Yang Mempengaruhi Produktivitas Tebu}

Produktivitas tebu di Indonesia dipengaruhi oleh harga gula ditingkat petani $\left(\mathrm{P}_{\mathrm{P}}\right)$, Rendemen tebu $\left(\mathrm{R}_{\mathrm{DMN}}\right)$, lag harga pupuk (P PUKt-1) dan lag produktivitas $\left(\mathrm{PRDV}_{\mathrm{t}-1}\right)$. Nilai $\mathrm{R}^{2}$ model persamaan ini yaitu 0,7182 yang menyatakan bahwa variabel $\mathrm{PRDV}_{\mathrm{t}}$ di Indonesia mampu dijelaskan oleh variasi variabel penjelasnya sebesar 71,82\%, sisanya dijelaskan oleh variabel lain diluar model persamaan.

Tabel.6 Hasil Parameter Faktor Yang Mempengaruhi Produktivitas Tebu

\begin{tabular}{ccccccc}
\hline & Coefficient & $\mathbf{t}_{\text {hit }}$ & $\mathbf{t}_{\text {tabel }}$ & $\mathbf{P}_{\text {value }}$ & Esr & Elr \\
\hline Constant & $-1,590347$ & $-1,34$ & & 0.183 & & \\
PP & $4,25 \mathrm{e}-08$ & 0,93 & & 0.356 & 0,47 & 1,89 \\
Rdmn & 0,7922336 & 5,85 & 2,13 & 0,000 & 1,03 & 1,41 \\
PruKt-1 & $-1.55 \mathrm{e}-07$ & $-1,38$ & & 0.172 & $-0,93$ & $-1,27$
\end{tabular}




\begin{tabular}{ccccccc}
$\mathbf{P R D V}_{\mathbf{t}-1}$ & 0,2690563 & 1,94 & & 0.056 & 0,27 & 0,36 \\
\hline $\mathbf{F}$ & \multicolumn{7}{c}{12,73} & & \\
$\mathbf{R}^{2}$ & & 71,41 & \\
\hline
\end{tabular}

Berdasarkan tabel diatas, didapatkan persamaan :

$\operatorname{Prdv}_{\mathrm{t}}=-\mathbf{1 , 5 9 0 3 4 7}+$ 4,25e-08 $\mathrm{P}_{\mathrm{P}}+$ 0,7922336dmn - 1.55e-07 PPUKt-1 + 0,269056PRDV $\mathrm{P}_{\mathrm{t}-1}$

Tabel 6 memperlihatkan produktivitas tebu secara parsial dipengaruhi secara nyata oleh rendemen tebu, pada tingkat kesalahan 5 persen. Rendemen adalah kandungan gula yang terdapat dibatang tebu yang dinyatakan dalam persen. Jika rendemen tebu meningkat sebesar $1 \%$ maka akan meningkatkan produktivitas tebu sebesar 0,7922336 Ha. Menurut P3GI (2008), meningkatkan nilai rendemen dapat dilakukan untuk meningkatkan produktivitas. Usaha menambah produktivitas melalui perbaikan rendemen tidak memerlukan biaya yang mahal tetapi dibutuhkan teknik yang tepat. Harga gula ditingkat petani, lag harga pupuk, dan lag produktivitas tidak berpengaruh nyata pada tingkat signifikansi $=0,05 \%$. Lag harga tingkat petani dan lag produktivitas berpengaruh positif produktivitas tebu, yang bermakna produktivitas tebu akan meningkat jika kedua variabel tersebut meningkat. Lag harga pupuk berpengaruh negatif terhadap produktivitas tebu, yang artinya jika harga pupuk tahun sebelumnya meningkat maka akan menurunkan produktivitas tebu. Menurut Diana et al (2016), tebu merupakan tanaman yang membutuhkan unsur hara yang tinggi, sehingga dalam budidaya tebu sepenuhnya diperlukan pemupukan. Oleh karena itu harga input salah satu pertimbangan untuk meningkatkan produktivitas.

\section{Faktor Yang Mempengaruhi Harga Gula Tingkat Petani}

Pada penelitian ini harga gula tingkat petani dipengaruhi oleh produksi tebu $\left(\mathrm{PR}_{\mathrm{t}}\right)$, harga gula impor $\left(\mathrm{P}_{\mathrm{IG}}\right)$, volume impor gula $\left(\mathrm{M}_{\mathrm{G}}\right)$, permintaan gula dalam negeri $\left(\mathrm{D}_{\mathrm{DN}}\right)$ dan lag harga gula tingkat petani $\left(\mathrm{P}_{\mathrm{Pt}-1}\right)$. Koefisien determinasi di model persamaan adalah 0,9274 , yang menunjukkan bahwa harga gula tingkat petani mampu dijelaskan oleh variasi variabel penjelasnya sebesar $92,74 \%$ dan sisanya dijelaskan variabel lain diluar model.

Tabel.7 Estimasi Faktor Yang Mempengaruhi Harga Gula Tingkat Petani

\begin{tabular}{|c|c|c|c|c|c|c|}
\hline & Coefficient & thitung & $t_{\text {tabel }}$ & $\mathbf{P}_{\text {value }}$ & Esr & EIr \\
\hline Constant & -2840888 & $-2,09$ & & 0,037 & & \\
\hline $\mathbf{P R}_{\mathbf{t}}$ & $-0,7830738$ & $-0,75$ & & 0,453 & 0,30 & 0,25 \\
\hline $\mathbf{P I}_{G}$ & 0,6235827 & 2,36 & 2,14 & 0,020 & 0,45 & 0,38 \\
\hline $\mathbf{M G}_{\mathbf{G}}$ & $-1,624715$ & -2.23 & & 0.029 & $-0,52$ & $-0,43$ \\
\hline D DN $_{\text {DN }}$ & 3,22969 & 3,18 & & 0.002 & 2,04 & 1,70 \\
\hline PPt-1 & $-0,2193404$ & $-0,74$ & & 0,462 & $-0,18$ & $-0,15$ \\
\hline $\mathbf{F}$ & \multicolumn{6}{|c|}{65,11} \\
\hline $\mathbf{R}^{2}$ & \multicolumn{6}{|c|}{92,74} \\
\hline
\end{tabular}

Bersumber pada tabel diatas, maka diperoleh persamaan harga gula ditingkat petani seperti dibawah ini :

$$
\begin{gathered}
P_{\text {petani }}=-2840888-0,7830738 P_{t}+0,6235827 P_{g i}-1,624715 M_{g}+3,22969 D_{D N} \\
-0,2193404 P_{\text {petani-1 }}
\end{gathered}
$$


Tabel 7 memperlihatkan bahwa secara parsial yang mempengaruhi harga gula pada tingkat petani secara nyata adalah harga impor gula, volume impor gula dan permintaan gula dalam negeri pada tingkat signifikansi 5\%. Nilai impor gula dan permintaan gula dalam negeri berpengaruh positif terhadap harga gula ditingkat petani. Artinya jika kedua variabel tersebut meningkat, maka akan meningkatkan harga gula tingkat petani sebesar koefisien variabel tersebut. Harga gula ditingkat petani dipengaruhi secara negatif oleh volume impor gula, artinya jika impor gula meningkat sebesar 1 ton maka akan menurunkan harga ditingkat petani sejumlah Rp. 1,6247. Menurut (Wulandari, 2017) ketergantungan Indonesia terhadap impor bahan pangan akan membahayakan Indonesia sendiri, karena resiko ketidakpastian situasi pasar pangan dunia. Impor bahan pangan dari luar negeri berdampak pada tingkat kesejahteraan produsen. Produsen adalah salah satu pihak yang paling dirugikan dengan adanya kebijakan impor. Hal ini diduga kecenderungan harga barang impor yang lebih murah menyebabkan produk lokal tidak mampu bersaing yang menyebabkan ketidakpastian harga. Akibatnya pada produsen tebu adalah turunnya minat mereka dalam membudidayakan tebu karena menganggap tebu bukanlah tanaman yang menguntungkan lagi.

\section{Faktor Yang Mempengaruhi Harga Impor Gula}

Harga gula impor $\left(\mathrm{P}_{\mathrm{IG}}\right)$ pada model persamaan ini dipengaruhi oleh harga gula dunia $\left(\mathrm{P}_{\mathrm{W}}\right)$, volume impor $\left(\mathrm{M}_{\mathrm{G}}\right)$, nilai tukar rupiah terhadap dollar (NT) dan lag tarif impor $\left(\mathrm{TI}_{\mathrm{T}-1}\right)$. Koefisien determinasi $\left(\mathrm{R}^{2}\right)$ adalah sebesar 0,9884, artinya variasi variabel penjelas mampu menjelaskan harga impor gula sebesar 98,82\% sedangkan $1,18 \%$ dijelaskan oleh faktor diluar model.

Tabel.8 Parameter Faktor Yang Mempengaruhi Harga Impor Gula

\begin{tabular}{|c|c|c|c|c|c|}
\hline & Coefficient & thit & ttabel & $\mathbf{P}_{\text {value }}$ & Esr \\
\hline Constant & -2851680 & $-9,55$ & & 0,000 & \\
\hline Pw & 8371,753 & 25,54 & & 0,000 & 0,73 \\
\hline $\mathbf{M G}_{\mathbf{G}}$ & $-0,2561403$ & $-4,14$ & 2,13 & 0,000 & $-0,12$ \\
\hline NT & 321,6468 & 10,16 & & 0.000 & 0,75 \\
\hline $\mathbf{T I}_{\mathrm{t}-1}$ & 0,7088275 & 4,61 & & 0.000 & 0,09 \\
\hline $\mathbf{F}$ & & & 428,07 & & \\
\hline $\mathbf{R}^{2}$ & & & 98,82 & & \\
\hline
\end{tabular}

Sehingga didapatkan model persamaan seperti dibawah ini

$P_{\text {gi }}=-2851680+8371,753 P_{W}-0,2561403 M_{G}+321,6468 \mathrm{NT}+0,7088275 \mathrm{TI}_{\mathrm{t}-1}$

Tabel 8 memperlihatkan harga impor gula dipengaruhi secara nyata oleh harga gula dunia, volume impor gula, nilai tukar rupiah, dan lag tarif impor gula pada tingkat signifikansi $5 \%$. Harga gula dunia, nilai tukar dan lag tarif impor berpengaruh positif terhadap harga impor gula, artinya jika terjadi peningkatan nilai dari variabel- variabel tersebut satu satuan, maka akan meningkatkan harga impor gula sebesar nilai koefisien regresinya. Harga yang terjadi dipasar internasional akan diteruskan ke pasar domestik, sebagai panduan dalam pembentukan harga domestik maupun harga ekspor/impor. Hal ini karena Indonesia bertidak sebagai price 
taker karena daya saing komoditi gula Indonesia di pasar dunia cenderung rendah sehingga tidak dapat mempengaruhi harga di dunia (Hidayati et al, 2017). Menurut Soekro et al (2008) fluktuasi nilai tukar dapat mempengaruhi harga komoditas impor, dimana saat nilai rupiah melemah (terdepresiasi), akan menyebabkan harga impor akan naik. Disisi lain, kebijakan peningkatan tarif impor dapat merangsang produsen domestik untuk meningkatan produksinya (Mira dan Saptanto, 2017). Impor gula memberikan pengaruh negatif terhadap harga impor, artinya apabila volume impor meningkat, maka harga impor akan menurun. Kondisi ini sesuai dengan teori penawaran dimana jika supply lebih besar maka harga akan turun. Variabel pada model ini bersifat inelastis (tidak responsif) pada harga impor, yang berarti bahwa jika terjadi perubahan $1 \%$ pada variabel dalam model hanya membawa perubahan yang kecil pada harga impor gula.

\section{Faktor Yang Mempengaruhi Volume Impor Gula}

Volume impor gula di Indonesia dipengaruhi oleh harga gula dalam negeri $\left(\mathrm{P}_{\mathrm{DN}}\right)$, harga gula dunia $\left(\mathrm{P}_{\mathrm{W}}\right)$, permintaan gula dalam negeri $\left(\mathrm{D}_{\mathrm{DN}}\right)$, nilai tukar rupiah (NT), pendapatan (Y) dan lag tarif impor $\left(\mathrm{TI}_{\mathrm{t}-1}\right)$. Hasil penelitian memperlihatkan nilai $\mathrm{R}^{2}$ adalah 0,8380 yang berarti volume impor gula di Indonesia mampu dijelaskan oleh variabel penjelasnya sebesar $83,80 \%$.

Tabel.9 Estimasi Faktor Yang Mempengaruhi Volume Impor Gula

\begin{tabular}{cccccc}
\hline & Coefficient & $\mathbf{t}_{\text {hit }}$ & $\mathbf{t}_{\text {tabel }}$ & $\mathbf{P}_{\text {value }}$ & Esr \\
\hline Constant & 1212815 & 1,44 & & 0,150 & \\
$\mathbf{P}_{\mathbf{D N}}$ & 0,4183996 & 3,32 & & 0,001 & 1,60 \\
$\mathbf{P}_{\mathbf{w}}$ & $-2644,771$ & $-2,37$ & 2,14 & 0,020 & $-0,52$ \\
$\mathbf{Y}$ & $-0,0202323$ & $-0,44$ & & 0.662 & $-0,18$ \\
$\mathbf{N T}$ & $-59,13721$ & $-0,73$ & & 0.467 & $-0,31$ \\
$\mathbf{T I} \mathbf{I}_{\mathbf{1}}$ & $-0,7252905$ & $-2,01$ & & 0,048 & $-0,23$ \\
\hline $\mathbf{F}$ & & & 20,99 & & \\
$\mathbf{R}^{2}$ & & & 83,80 & & \\
\hline
\end{tabular}

Berdasarkan tabel diatas, didapatkan persamaan seperti dibawahh ini :

$M_{G}=-1212815+0,4183996 P_{D N}-2644,771 P_{W}-0,0202323 \mathrm{Y}-59,13721 \mathrm{NT}$

$-0,7252905 \mathrm{TI}_{\mathrm{t}-1}$

Hasil penelitian menunjukkan variabel yang berpengaruh nyata secara parsial terhadap volume impor gula ialah harga gula domestik, harga gula dunia dan tarif impor tahun sebelumnya pada tingkat kepercayaan 95\%. Harga gula domestik memberikan pengaruh positif terhadap volume impor, yang bermakna apabila harga gula domestik naik Rp. 1 akan meningkatkan volume impor sebesar 0,418 ton. Impor dan ekspor bergantung perubahan tingkat harga yang terjadi (Ekananda 2015 dalam Prafajaria et al, 2016). Artinya apabila terjadi perubahan harga didalam negeri maka akan berdampak pada perubahan kuantitas jumlah impor maupun ekspor. Impor dilakukan jika terjadi peningkatan harga dalam negeri. Harga gula dunia dan tarif impor gula memberikan pengaruh negatif 
terhadap impor gula, dimana jika harga gula dunia dan lag tarif impor gula meningkat maka akan mengurangi volume impor. Kondisi ini sesuai dengan hukum permintaan, yang mengatakan apabila harga gula dipasar dunia mengalami peningkatan maka permintaan impor terhadap komoditi tersebut akan berkurang. Menurut (Kustiari, 2013), pemberlakuan bea masuk untuk melindungi produsen domestik dari harga rendah, dengan diberlakukannya bea masuk terhadap produk-produk impor harga barang impor akan naik sehingga permintaan impor akan menurun.

\section{Faktor Yang Mempengaruhi Harga Gula Domestik}

Harga gula dalam negeri dipengaruhi oleh harga gula tingkat petani $\left(\mathrm{P}_{\mathrm{P}}\right)$, harga gula dunia $\left(\mathrm{P}_{\mathrm{W}}\right)$, impor gula $\left(\mathrm{M}_{\mathrm{G}}\right)$, nilai tukar rupiah $(\mathrm{NT})$ dan lag harga gula $\left(\mathrm{P}_{\mathrm{DN} \mathrm{t}-1}\right)$. Nilai $\mathrm{R}^{2}$ sebesar 0,9901 yang mengatakan bahwa variasi variabel penjelas mampu menjelaskan variabel harga gula dalam negeri sebesar 99,01\%.

Tabel. 10 Estimasi Faktor Yang Mempengaruhi Harga Gula Domestik

\begin{tabular}{ccccccc}
\hline & Coefficient & $\mathbf{t}_{\text {hit }}$ & $\mathbf{t}_{\text {tabel }}$ & $\mathbf{P}_{\text {value }}$ & $\mathbf{E s r}$ & Elr \\
\hline Constant & -1474280 & $-2,53$ & & 0,013 & & \\
PP $_{\mathbf{P}}$ & 0,7045646 & 5,80 & & 0,000 & 0,58 & 0,84 \\
$\mathbf{P W}_{\mathbf{W}}$ & 550,7286 & 0,57 & 2,13 & 0,573 & 0,02 & 0,03 \\
$\mathbf{M}_{\mathbf{G}}$ & 0,5065434 & 2,46 & & 0.016 & 0,14 & 0,20 \\
NT & 135,0291 & 2,23 & & 0,029 & 0,19 & 0,28 \\
$\mathbf{P}_{\text {DNt-1 }}$ & 0,3082455 & 2,85 & & 0.009 & 0,29 & 0,42 \\
\hline $\mathbf{F}$ & & 491,20 & & \\
$\mathbf{R}^{\mathbf{2}}$ & & 99,01 & & \\
\hline
\end{tabular}

Sehingga diperoleh persamaan seperti dibawah ini :

$$
\begin{aligned}
& P_{D N}=-1474280+0,7045646 P_{P}+550,7286 P_{W}+0,5065434 M_{G}-135,0291 N T \\
& \quad-0,3082455 P_{D_{t}-1}
\end{aligned}
$$

Tabel 10 memperlihatkan bahwa secara parsial faktor yang berpengaruh nyata terhadap harga gula domestik ialah harga gula ditingkat petani, volume impor gula, nilai tukar dan lag harga gula domestik. Harga ditingkat petani berpengaruh positif terhadap harga gula domestik, yang berarti jika harga ditingkat petani men Rp.100 maka akan meningkatkan harga gula domestik sebesar Rp. 70,45646. Hal ini terjadi karena harga gula domestik (enceran) didasarkan pada harga tingkat petani ditambah keuntungan distributor dan pengencer (Oktariani, 2007). Impor gula berpengaruh positif terhadap harga gula domestik. Menurut Wahyunidyawati dan Sari (2018), harga gula domestik meningkat akibat pengaruh dari faktor lain yang tidak dapat diukur, yaitu pengaruh para samurai yang dapat menaikkan harga gula tanpa sebab yang jelas dan tidak ada pihak yang dapat menengarai bahwa kenaikan itu adalah disebabkan karena sesuatu yang tidak beralasan. Nilai tukar rupiah berpengaruh positif terhadap harga gula domestik artinya jika nilai tukar naik (terdepresiasi/melemah) akan menaikkan harga gula domestik. 


\section{Kesimpulan dan Saran}

Trend impor gula dan harga gula domestik mengalami peningkatan, sementara disisi lain trend produksi tebu cenderung menurun. Hasil proyeksi selama 5 tahun kedepan: impor gula, produksi tebu dan harga gula domestik akan terus meningkat, namun pertumbuhan produksi tebu selama periode proyeksi relatif rendah setiap tahunnya.

Hasil persamaan simultan menunjukkan: (a) Harga gula ditingkat petani dan lag luas areal berpengaruh positif dan signifikan terhadap luas areal tebu. (b) Harga gula ditingkat petani dipengaruhi secara signifikan dan positif oleh harga impor gula dan permintaan gula dalam negeri. Sementara volume impor berpengaruh negatif terhadap harga gula ditingkat petani. (c) harga gula dunia, nilai tukar rupiah dan lag tarif impor gula berpengaruh positif dan signifikan terhadap harga impor gula, sementara jumlah impor berpengaruh negatif. (d) Harga gula dalam negeri berpengaruh positif dan signifikan terhadap volume impor gula, tetapi harga gula dunia dan lag tarif impor berpengaruh negatif. (e) Harga gula dalam negeri dipengaruhi secara signifikan dan positif oleh harga gula dipetani, jumlah impor gula, nilai tukar dan lag harga gula domestik tahun sebelumnya

Peningkatan impor gula berdampak pada menurunnya produksi tebu, karena volume impor berpengaruh terhadap penurunan harga gula di tingkat petani. Artinya semakin tinggi impor gula, maka akan menurunkan harga gula tingkat petani. Disisi lain, harga gula ditingkat petani berpengaruh positif terhadap luas areal dan produktivitas tebu. Oleh karena itu apabila harga gula dipetani turun maka akan menurunkan luas areal dan produktivitas yang akhirnya akan berdampak pada penurunan produksi tebu di Indonesia.

Peningkatan impor juga memberi dampak pada peningkatan harga gula domestik, hal ini disebabkan oleh turunnya produksi tebu, yang berpengaruh terhadap turunnya produksi gula domestik. Ketidakseimbangan antara produksi yang rendah dan permintaan yang tinggi akan berdampak pada peningkatan harga gula domestik.

Dalam usaha meningkatkan produksi gula dalam negeri untuk mencapai swasembada gula, baik petani maupun pemerintah, sebaiknya lebih difokuskan pada perluasan area tanam tebu, peningkatan produktivitas melalui peningkatan rendemen, penyediaan bibit unggul dan subsidi pupuk, menciptakan harga yang menarik bagi petani serta penggunaan teknologi panen maupun pasca panen.

Kestabilan harga gula tingkat petani dapat dilakukan dengan menaikkan harga gula impor, mengurangi impor dan meningkatkan tarif. Kebijakan bea masuk bagi gula impor sangat diperlukan untuk proteksi terhadap liberalisasi perdagangan yang sudah berlangsung.

Perlunya upaya pemerintah untuk mestabilkan harga gula domestik dengan menindak tegas pihak-pihak yang mempermaikan harga gula di pasar Indonesia 


\section{DAFTAR PUSTAKA}

Andriyanto, T. 2012. Pengaruh Letter Of Intent (LoI) IMF Terhadap Pelemahan Ketahanan Pangan Beras Indonesia 1995-2009. Skripsi. Universitas Indonesia, Depok

APTRI, 2018. Pemerintah Impor Gula Mentah, Petani Menangis. https://www.aptri.or.id/aptripemerintah-impor-raw-sugarpetani-nangis/

Arifin, B. 2008. Ekonomi Swasembada Gula. Universitas Lampung, Lampung Bank Indonesia, 2007. Laporan Angka Inflasi di Indonesia. BI. Jakarta.

Diana, N.E., Supriyadi., dan Djumali. 2016. Pertumbuhan, Produktivitas, dan Rendemen Pertanaman Tebu Pertama (Plant Cane) Pada Berbagai Paket Pemupukan. Jurnal Ilmu Pertanian, 21(3) :159166.

Hidayati, S., Darwanto, D.H., dan Mayshuri. 2017. Kinerja Ekspor Tuna Indonesia-Kajian Mengenai Faktor Yang Mempengaruhi Ekspor Tuna Indonesia di Pasar Jepang, Amerika Serikat dan Korea Selatan. Andi Offset, Yogyakarta.

Mira dan Saptanto, S. 2017. Pengaruh Kebijakan Perubahan Tarif Impor Terhadap Sektor Kelautan Dan Perikanan. Jurnal Kebijakan Sosek KP Vol. 7 No.1:13-25. Balai Besar Riset Sosial Ekonomi Kelautan Dan Perikanan, Jakarta.

Nusantara Sugar Club. 2014.

Perkembangan Pergulaan

Nasional Januari 2014. Jurnal

Gula, 1 (1) : 1-3.

Okatriani, A. 2007.Analisis Faktor-Faktor Yang Mempengaruhi Harga Gula Domestik Dan Pengaruh
Pergulaan Nasional. Institut Pertanian Bogor, Bogor

P3GI. 2008. Konsep Peningkatan Rendemen Untuk Mendukung Program Akselerasi Industri Gula Nasional. Pusat Penelitian Perkebunan Gula Indonesia. Surabaya.

Prafajarika, S.W., Yulianto, E., dan Wilopo. 2016. Pengaruh Nilai Tukar, Harga Dalam Negeri Dan Harga Internasional Terhadap Volume Impor Daging Sapi Indonesia. Jurnal Administrasi Bisnis $\quad(J A B) \quad$ Vol.34 No.1. Universitas Brawijaya, Malang

Soekro, S.R.I., Herlianto, A., Amrozy, M.T., Susilorini, S.E., Padoli, G. Bangkitnya Perekonomian Asia Timur Sat Dekade Setelah Krisis. Biro Hubungan Dan Studi Internasional Bank Indonesia. PT Gramedia, Jakarta.

Wahyuni, S., Supriyati, dan Sinuraya. 2009. Industri dan Perdagangan Gula di Indonesia : Pembelajaran dari Kebijakan Zaman Penjajahan Sekarang. Jurnal Penelitian Agro Ekonomi, 27 (2) : 2-13.

Wahyunidyawati dan Sari, D. 2017. Samurai Yang Mempengaruhi Harga Gula Indonesia ?. Balai Pengkajian Teknologi Pertanian, Malang.

Wulandari, S.S. 2017. Kebijakan Pemerintah Indonesia Dalam Melindungi Petani Lokal Dari Ancaman Impor Kedelai Amerika Serikat Tahun 2012-2016. JOM FISIP Vol.4 No.2. Universitas Riau, Riau. 